\title{
Research into stress-strain state of the rock mass condition in the process of the operation of double-unit longwalls
}

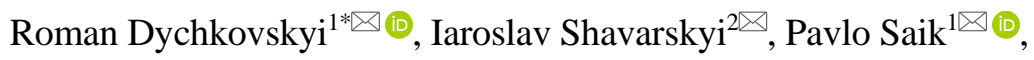

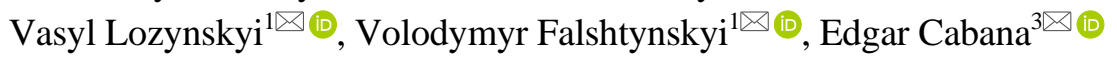 \\ ${ }^{1}$ Dnipro University of Technology, Dnipro, 49005, Ukraine \\ ${ }^{2}$ JARAD Recycling Technology Sp. z o.o., Smolnica, 40-166, Poland \\ ${ }^{3}$ Universidad Nacional de San Agustin de Arequipa, Arequipa, 4100, Peru \\ *Corresponding author: e-mail dychkovskyi.r.o@nmu.one, tel.+380567446214
}

\begin{abstract}
Purpose. To substantiate changes in stress-strain state of rock mass in the process of long-pillar mining with the help of double-unit longwalls while evaluating stress of a mine field in terms of Lvivvuhillia SE mine.

Methods. Analysis of the plans of mine workings has become a basis for the evaluation of physical and geometrical parameters of a support pressure area of the double-unit stopes depending upon mining and geological as well as engineering conditions for $n_{7}^{b}$ coal seam extraction. 3D model of the rock mass has been rendered using SolidWorks 2019 software. The geomechanical model of the rock mass is based upon the specified output data concerning actual operating schedule of 1018 and 1019 double-unit longwalls (numbers of the longwalls are changed as it has been required by the authorities of Lvivvuhillia SE) in terms of $n_{7}^{b}$ seam and support patterns of the development mine workings in Lvivvuhillia SE mine. Each component of the support was modeled as a separate part with the relevant geotech data. Behaviour of the expansion of the rock mass stress-strain state within the selected point has been analyzed by means of sections at the specified plane.

Findings. Rendering algorithm of 3D model of rock mass in terms of long-pillar mining of a coal seam using double-unit longwalls has been developed. A geomechanical model of the rock mass has been substantiated depending upon the mining and geological mode of occurrence and engineering parameters of coal mining process.

Originality. Nature of the support pressure area formation in front of a stope as well as along the extraction pillar length has been analyzed. It has been identified that if stopes are within one and the same plane, interconnection of their frontal support pressure areas as well as walls of the development workings take place. In this context, adjoining entry acts as the extra destressing technogenic cavity in addition to its proper functions.

Practical implications. Output data to make recommendations concerning the efficient mining parameters and methods for rock pressure control have been identified relying upon the analysis of stress-strain state of rock mass in the process of the operation of double-unit longwalls. Visualization of the principles of formation of the stress-strain state of support pressure area and evaluation of the rock mass condition have shown that the maximum reduced stresses reach $70 \mathrm{MPa}$ in terms of $18 \mathrm{~m}$ width of the support pressure area.
\end{abstract}

Keywords: mine, coal, rock mass, double-unit stopes, mine working, stress-strain state

\section{Introduction}

Currently, the improved efficiency of mines is the critical and topical problem since it is focused on the improvement of energy independence of our state [1]. Concentration and intensification of mining in terms of the implementation of innovative mining equipment is the key tendency of such enhancement [1]-[4] However, purchase of new facilities, unadopted to the definite mining and geological conditions, is connected with certain risks [5]-[7]. Rather often the substantiated significant financial expenditures are followed by the necessity to introduce changes in job skills of employ- ees. Unfortunately, urgent retraining of personnel and gaining practical experience takes place when the equipment is operating [8]. Consequently, not infrequently mining enterprises start using new more modern facilities unwillingly preferring job-proved mechanized systems and other extractive mechanisms [9], [10].

Currently, it is proposed the technological methods of coal mining, which are focused on combining several technologies within a single mining enterprise [11], [12], mining coal reserves in difficult geological conditions, improving the environmental quality [13]-[16] and processing waste on the surface [17], [18]. New radical technologies in which the 
mineral source is transferred to another physical state by means of complex thermochemical transformations were developed for extracting thin coal seams [19]-[23]. Particular attention during conventional mining is paid to the management of stress and pressure in mining to ensure the manufacturability of this process [24], [25]. The creation of artificial shells in the rock of the passage of purge mixtures is an effective way to obtain an appropriate material and thermal balance of gasification [26], [27]. However, these changes require significant financial injections and reorientation of production [27]-[31].

The research is aimed at the improvement of mine efficiency while applying the available technological infrastructure. Increase in the involved extraction areas (i.e. mining concentration) is one of the extensive methods to improve efficiency of mines (in terms of invariable technical support). It has been proved practically that the double-unit stopes make it possible to increase drastically coal output in terms of the reduced operating costs during the limited time intervals and with extra financial injections [3], [32].

The idea of such a technological improvement is simultaneous putting into operation of two (sometimes three) longwalls operating within the area of dynamic changes in stresses developed by the stopes [33]-[37]. Moreover, their activities will be supported by one conveyor system and a joint district ventilation network.

\subsection{Unsolved parts of the general problem}

The paper authors estimate stress-strain state of rock mass in terms of two longwalls operating without advance. The research has been carried out under the actual conditions of one of the mines belonging to Lvivvuhillia SE.

Rather frequently, in the context of such an operation schedule the reserves are extracted by separate winning machines used for each of the stopes; the cut coal is conveyed by one common scraper. The procedure involves a number of requirements to its use [38]-[42]. First of all, it concerns high efficiency of the conveyor system to provide the motion of total mass of the coal cut in the two extraction pillars [43], [44]. The abovementioned results in the increased power consumption [45]-[47] and in the ventilation problems [48]-[51].

That is why we analyze two simultaneously operating longwalls (i.e. in one line) but equipped with absolutely autonomous mechanized systems. The only common belt entry is used for common conveying of the cut coal. On the other hand, such an operation schedule will make it possible to analyze in future the technical and technological as well as geomechanical situation in terms of other spatial representation of stopes.

\subsection{Research tasks}

The purpose of the paper to analyze stress-strain state of rock mass in the process of long-pillar mining using doubleunit longwalls involves solution of the interrelated problems:

- analysis of mining and geological as well as engineering characteristics of the site under study; collection of the data concerning stress-strain properties of the analyzed area, materials etc.;

- development of geomechanical model of rock mass in terms of long-pillar mining using double-unit longwalls; substantiation of the model parameters;

- performing a calculation experiment to form database as for the model; verification of the research results;
- identification of rock mass stress values being the data for recommendations concerning efficient reserve mining using the double-unit longwalls and rock pressure control.

\section{Methodology}

\subsection{Initial modeling data}

Mining and geological as well as technical and technological situations of one of Lvivvuhillia SE mines are the initial modeling data. Within a site, where coal is mined from $n_{7}$ b seam, use of the double-unit stopes with their functional lagging from one another has been proposed to improve the efficiency of mining. The distance is determined by the means of geomechanical stability of the mine workings, ventilation, and economic expediency.

Within the site to be mined, coal seam is rather continuous as for its thickness and hypsometry. Geological thickness of the deposit is $0.90-1.60 \mathrm{~m}$; its average mining thickness is $1.24 \mathrm{~m}$. Therefore, minor undercutting of wall rocks is involved inside the site of a mine field. Relying upon lithological structure of the carbonous formation, it is expedient to cut the seam roof.

Clarain-durain humus forge coal according to Ukrainian coal rank (volatiles in wt $-30 \%$ ) with fusain inclusions occurs within the mine field share. The coal is slightly fissured; it is not prone to spontaneous combustion. Coal dust is explosive. Contacts of the coal seam with surrounding floor and roof rocks are smooth and clear enough with minor substitution of the power generating coal by sapropelite inclusions.

\subsection{Geology}

The seam floor is represented by sand shale sometimes interlaying with sandstone. Aleurite is dark grey within the upper share of a lumpy structure of a "kucheriavchyk" type (so called "curly" exfoliating rocks) with phytoleims. It is laminated, micaceous lower through the geological section. The seam thickness is up to $5.65 \mathrm{~m}$.

Stable sand shales and sandstones occur within the floor rocks. Rock stratification under the coal seam results in the impossibility to separate clearly the floor into the immediate floor and basic one. Hence, in terms of the standard classification, the seam floor is considered as a stable. The rocks intersect the coal seam as straight lines with kucheriavchyk (less stable carbonized form) appearing on the contact. Total thickness of the floor rocks varies from 5.2 to $11.1 \mathrm{~m}$.

The data obtained according to structural columns of prospect wells, help understand that the immediate roof of the coal seam is represented by semi-solid and semi-stable clay shale (aleurite and argillite) with 1.32-3.91 m thickness variation. The averaged values of physical, geological, and deformational characteristics of carbonous formation are shown in the Table 1.

On the contact with the coal seam, a lower part of the immediate roof is represented by coal-clay shale or by sapropelic coal which failures right after outcropping in the process of coal mining. Slickensides are observed on clay shale and coal-clay shale contact. In terms of a tectonic structure, sites of the two longwall (we mean: longwalls 1018 and 1019; changed at the request of Lvivvuhillia SE authorities) is characterized by average complexity. Intensity of the immediate rock fracturing corresponds to the general trend of the fissures (in terms of the two systems: northeast (basic) directivity and northwest one) being 3-6 fissures $/ \mathrm{m}$. 
Table 1. The averaged values of physical, geological, and deformational characteristics of carbonous formation of $\boldsymbol{n}^{b}$ seam in one of Lvivuhillia $S E$ mines

\begin{tabular}{|c|c|c|c|c|c|c|c|c|c|}
\hline No & Name & $\mathrm{m}$ & $\begin{array}{c}R_{c}, \\
\mathrm{MPa}\end{array}$ & $\begin{array}{c}R_{t}, \\
\mathrm{MPa}\end{array}$ & $\mu$ & $E$ & $\begin{array}{c}\rho, \\
\mathrm{kg} / \mathrm{m}^{3}\end{array}$ & $\begin{array}{c}\varphi, \\
\text { degrees }\end{array}$ & $C, \mathrm{MPa}$ \\
\hline \multicolumn{10}{|c|}{ Floor } \\
\hline 1 & Sandstone & 8.0 & 43.7 & 2.3 & 0.22 & 13232 & 2610 & $0-23$ & \\
\hline 2 & Aleurite & 3.3 & 48.9 & 3.3 & 0.19 & 11341 & 2650 & $25-35$ & $1.5-2.0$ \\
\hline 3 & Sandstone & 3.0 & 116.6 & 4.3 & 0.32 & 26 & 2640 & $25-35$ & \\
\hline 4 & Coal $n_{7}^{\mathrm{b}}$ & 0.95 & 24.5 & 1.8 & 0.17 & 0 & 2560 & $25-35$ & $1.0-1.3$ \\
\hline \multicolumn{10}{|c|}{ Immediate roof } \\
\hline 5 & Argillite & 1.0 & 22.9 & 1.3 & 0.22 & 3453 & 2670 & $25-35$ & $1.5-2.0$ \\
\hline 6 & Aleurite & 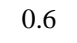 & 54.9 & 3.4 & & & 2660 & $25-35$ & \\
\hline 7 & Arg & & 22.9 & 1.3 & 0.22 & & 2670 & $25-35$ & \\
\hline \multicolumn{10}{|c|}{ The basic roof with loaded rocks } \\
\hline 8 & Ale & 2.1 & 45.3 & 2.4 & 0.24 & 9560 & 2640 & $25-35$ & $1.5-2.0$ \\
\hline 9 & Sandstone & 3.6 & 64.7 & 2.3 & & & 2630 & 35 & \\
\hline 10 & Coal & 1.2 & 2 & 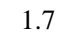 & & & 2660 & $25-35$ & $1.0-1.5$ \\
\hline 11 & Argillite & 1.1 & 15.9 & 0.9 & 0.20 & 2342 & 2750 & $25-35$ & $1.5-2.0$ \\
\hline 12 & Aleurite & 0.6 & 150 & 0.8 & 0.20 & 2432 & 2640 & $25-35$ & $1.5-2.0$ \\
\hline 13 & Argillite & 2.3 & 25.4 & 0.6 & 0.25 & 4439 & 2670 & $25-35$ & $1.5-2.0$ \\
\hline 14 & Aleurite & 3.0 & 17.0 & 12 & 0.22 & 25 & 2670 & $25-35$ & $1.5-2.0$ \\
\hline 15 & Sandstone & 3.6 & 63.4 & 2.7 & 0.28 & 17844 & 2640 & 32 & 2.0 \\
\hline 16 & Aleurite & 1.0 & 33.0 & 1.8 & 0.25 & & 2660 & $25-35$ & $1.5-2.0$ \\
\hline 17 & San & 0.9 & 54.1 & 2.4 & 0.24 & & 2630 & 32 & 2.0 \\
\hline 18 & Arg & 1.2 & 43.4 & 0.6 & 0.24 & & 2660 & $25-35$ & $1.5-2.0$ \\
\hline 19 & Ale & 0.6 & 36.0 & 1.9 & 0.23 & & 2670 & $25-35$ & $1.5-2.0$ \\
\hline \multicolumn{10}{|c|}{ Bridge rock } \\
\hline 20 & Aleurite & 1.2 & 18.1 & 1.0 & 0.21 & 4184 & 2650 & $25-35$ & $1.5-2.0$ \\
\hline 21 & Sand & 5.9 & 43.3 & 2.1 & 0.25 & & 2600 & $21-24$ & 2.3 \\
\hline 22 & Argillite & 4.2 & 23.2 & 0.8 & 0.25 & 4232 & 2665 & $25-35$ & $1.5-2.0$ \\
\hline 23 & Burden & 321.0 & 44.5 & 1.2 & 0.22 & 7172 & 2590 & 20 & 1.8 \\
\hline
\end{tabular}

The seam main roof is represented by dense mica sand schists with horizontally layered structure. Within the mine field site, the main roof thickness varies from 3.81 to $6.15 \mathrm{~m}$.

Caving step of the immediate roof is:

$-l i_{0}-1.3$ m initial;

$-l i_{1}-0.8 \mathrm{~m}$ the following.

Caving step of the main roof is:

$-\left(l_{m 0}\right)-12-16$ initial;

$-\left(l_{m 1}\right)-6-10 \mathrm{~m}$ the following.

The first rigidity layer (i.e. bridge rock) occurs over the main roof rocks almost at $25-30 \mathrm{~m}$ distance from $n_{7}^{b}$ seam roof. The bridge rock is represented by sandstone-argillite interlayers. Caving step of the rocks is more than $80 \mathrm{~m}$. It should be mentioned that the mined-out coal seam $n_{7}$ occurred between the main roof and the bridge rock. Its extraction resulted in partial destressing of the rock mass. Hence, the bridge rock "supports" on the rocks of a formation in front of the stope and on the caved rocks behind a working ranges of the longwall. Within the stope space, elastoplastic deformations of the bridge rock are observed. Hence, at the rock height, the mechanized support of the stope will not be surcharged.

\subsection{Technical and technological support of the extraction process}

To mechanize mining in the two stopes the powered MDM systems with section of the powered support DM will be applied. Coal shearers RKU-10 will be used as mining machines in the first longwall and UKD 200-250 in the second one. SP-26U scrapers will convey the cut coal from the rock mass along the longwall. Oil-pumping station SNT 32 will supply a working mixture to the powered system to maintain pressure of emulsion.

Extraction pillars of the mine longwalls 1018 and 1019 have been outlined by boundary entries 1018 and 1020, and a belt entry 1019 respectively. Three-component arcwall flexible support AP-3 was applied for the development mine workings. Cross-sectional area of the development mine workings is: $10.3 \mathrm{~m}^{2}$ for boundary entry $1018 ; 10.3 \mathrm{~m}^{2}$ for belt entry 1019 ; and $10.6 \mathrm{~m}^{2}$ for boundary entry 1020 . Belt entry 1019 will become a mother entry for both longwalls. It will be used to convey the cut coal to the main haulage roads. Then, the coal will get to a hopper and skips will deliver it to the surface.

Hence, formulation of the scientific and applied problem is to provide the required support stability of both mine workings and development workings for the period of coal extraction from the two stopes. The abovementioned involves solving a problem concerning determination of interaction in the context of geomechanical environmenttechnogenic space system in terms of simultaneous mining of two double-unit stopes. Further research should identify lagging (distance) boundary between the stopes of longwalls 1018 and 1019. The activities are intended to determine efficient distances of advance of the longwalls during their simultaneous operation.

\subsection{Formation of the simulation model}

Relying upon the print-out of plans of longwalls 1018 and 1019 in a mine of Lvivvuhillia SE, we have formed a visualizing model of the mine field site with outcropping in terms of the two provisional contact planes: floor of the coal seam (area of rock caved behind the longwall), and the coal seam roof (front abutment pressure). Figure 1 demonstrates the model. Stress-strain state of the rock mass should be analyzed right for the outcrop area. Moreover, the fact that geological parameters of stopes and lithological structure are simulated with the use of principles of statistical modeling of the reality, should be taken into consideration. Physical parameters are variables. Thus, the known principles for stressstrain state of rock mass evaluation will be applied.

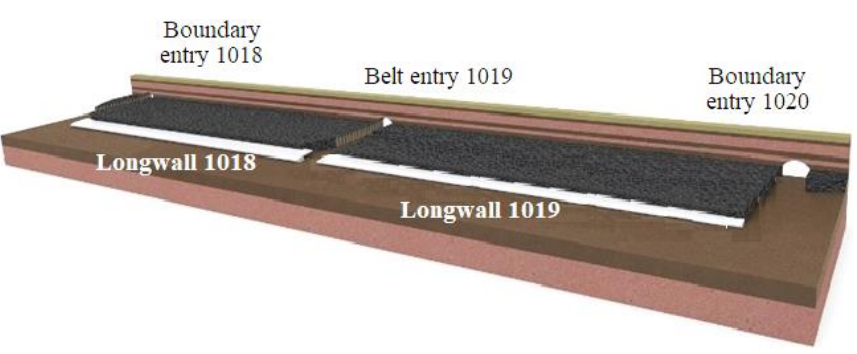

Figure 1. 3D section of the rock mass models in terms of long-pillar mining of $n^{b}$ coal seam using the double-unit longwalls

Relying upon lithological structure of the roof rocks and rock pressure control in the mine (complete caving, $l_{i 0}=1.3 \mathrm{~m}$; and $l_{i 1}=0.8 \mathrm{~m}$ ), it is possible to conclude that the immediate roof will cave right after the stope advance. According to the available deformation characteristics of the carbonous formation (prior geological forecast of the mines on the data of prospect wells), average uniaxial strength of the stratified sand shales within the main roof is $R_{c}=23.2-31.1 \mathrm{MPa}$. Softer rocks occur between the main roof and the bridge rock (the first rigidity layer). Uniaxial strength of the softer rocks is $19.0-24.1 \mathrm{MPa}$. 
Consequently, deformation of the rocks depends upon the main roof rock fault. Since strength of the interlayers exceeds relevant indices of the main roof within the certain areas, overhanging of the rocks is possible as well as the development of stratification areas within the percarbonic formation and high rock pressure areas. First of all, it will depend upon stope advance and possibilities to destress the rock mass.

Since the evaluation of stress-strain state of rocks around mine workings will involve software package based upon the development of finite-element system of the environment, the amount of rocks being analyzed should be approximated with the help of certain freeform discrete elements [52], [53]. In terms of the solids, it is required to simulate the basic physical and mechanical characteristics being typical for the rock mass within the specified area under analysis [54], [55]. Water filtration processes in these terms must be also considered [56]-[58].

Formation of the model and the research should involve interpolation of subordination of the key factors and determination of their interaction through communication nodes [59]-[61]. Practically, the nodes are vertices of the solids with the help of which the carbonous formation is divided into the separate elements. They are the benchmarks to evaluate stress of the analyzed areas and volumes [63], [63]. Changes in the rock mass stress is identified by means of identity of values obtained between them. Accuracy of the final results is provided owing to the use of the relevant principles of elastoplastic or plastic deformations and densification or coarsening of networks of the solids depending upon the required accuracy of the final results [64]-[66].

Essential freedom in the formation of parameters of the modeled ultimate parts is the positive feature of such an approach to determine stress and strain characteristics of the rock mass [67]-[69]. In addition to the normatively established values (i.e. rock resistance to uniaxial pressure, tension, and cut; volume deformation modulus; volume weight; elasticity modulus; coefficient of internal friction; adhesion factor and other specified parameters), each inciting factor makes it possible to introduce additional coefficients and factors to provide correspondence of the final results of stress-strain state as well as the behaviour of the certain model object, and nature object rocks [70]-[72].

The modeling process also involves geological structure variation, changes in the coal seam hypsometry as well as surrounding layers of intact rocks, their thinning or replacement by other structures [73]-[76]. Setting simplicity of the environment discontinuity, adding of the required characteristics to the definite components also helps simulate adequately changes in technical and technological situation.

\subsection{Algorithm for the data entering, processing, actualizing, and results withdrawing}

The process of preparing the geometrization data and to develop finite-element models and to analyze stress-strain state should involve a clear procedure [19], [77]. That is why to simulate mining and geological as well as technological conditions of longwalls 1018 and 1019 in one of Lvivuhillia SE mines, we applied following algorithm for the data entering, processing, actualizing, and results withdrawing:

- analysis of lithological variation and determination of physical characteristics of certain rocks;

- limitation of modeling geometry (i.e. height, width, and length of the area being modeled) available in the technogenic cavities of stopes and development mine workings;
- use of regularities of elastic as well as elastoplastic deformations to evaluate strength of the areas under analysis;

- selection of the ultimate object shape (i.e. elements of the area being modeled) to simulate the rock mass stress: regular triangular pyramid;

- determination of the values of extra applied stresses;

- modeling of a finite-element network of the rock volume under analysis with its densification while nearing working spaces of stopes and development mine workings;

- determination of the boundary modeling conditions and identification of limits within which relevance of the final result will be provided;

- the modeling sequencing in accordance with the regularities of conservation of mass, energy, and potential for their exchange in the contacts of ultimate figures;

- setting of appropriate structural feature and physical characteristics to geological bodies of the coal seam and to surrounding dead rocks;

- actualization of the model formation to increase probability degree of the obtained final results;

- determination of regularities of stress field expansion as well as deformation characteristics of the rock mass;

- withdrawal of the final results in the form of visual representation of distribution of the stress model as well as values of the roof rock displacement in terms of the certain planes.

Hence, using the stresses, the modeling helps determine rock displacement and stress distribution within the areas of support pressure of the rock mass. In our case, the data will be applied to evaluate relevance of the mining equipment intended to be used under the specific mining and geological conditions of the double-unit 1018 and 1019 longwalls in one of Lvivuhillia SE mines.

The averaged physical, geological, and deformational characteristics of the rock mass within a site of the meant double-unit 1018 and 1019 longwalls will be output data of the modeling. The carbonous formation involves $n_{7}^{\mathrm{b}}$ coal seam which is planned to be mined with the help of the powered systems MDM.

The developed in Dnipro University of Technology software for the coal seams mining simulation [78], [79] unfortunately have some problems of its implementation. So, popular software program SolidWorks 2019 corresponds entirely to the ideas of modeling, determination of stresses and deformational characteristics of rocks. It is based upon the use of the known Hoek-Brown criterion [80], [83]. Relying upon the statistical processing of homogenous rocks, the criterion describes rock mass disintegration. Moreover, it is also a standard to provide output data in the process of underground mine working design in terms of various rock masses. It has been derived while determining boundary strength values of the undisturbed rock mass. The research has been carried out by Everet Hoek [84]. Then the criterion was improved while identifying behaviour of certain samples under the deformation within continuous system with mass preservation (Brown's principle) [85].

Practical background of Hoek-Brown criterion relies upon empirical deformational characteristics using the principles of continuum mechanics [86], [87]. The criterion is added by the relevant compensation factors to identify higher correspondence to the actual conditions. The authors connect the empirical coefficients with the results of real observations about the behaviour of geological and lithological structures of the analyzed sites of the mine field. 


\section{Results and discussion}

The modeling corresponded to the generally accepted approach by means of developing a network of finite-element units. As it has been mentioned, triangular component, being a basis of a regular pyramid, has been taken up as the ultimate flat component to shape the model. Lithological and structural features of rock mass of the modeled area are simulated with distance changes between the stopes from 0-0 $\mathrm{m}$ (the double-unit longwalls) up to $60 \mathrm{~m}$ (maximum distance at which the longwalls operated within "the double-unit longwalls" system) with $20 \mathrm{~m}$ pitch. However, the paper considers formation of model one only, anticipating that the distance between 1018 and 1019 longwalls is $0 \mathrm{~m}$ (advance level is $0-0 \mathrm{~m}$ ).

Evaluate field stress of the analyzed areas with the help of determination of the reduced stresses. Figure 2 shows volumetric representation of a model of stress-strain state of the rock mass obtained with the help of SolidWorks 2019 software in terms of the double-unit mining longwalls under the specific conditions of one of Lvivuhillia SE mines.

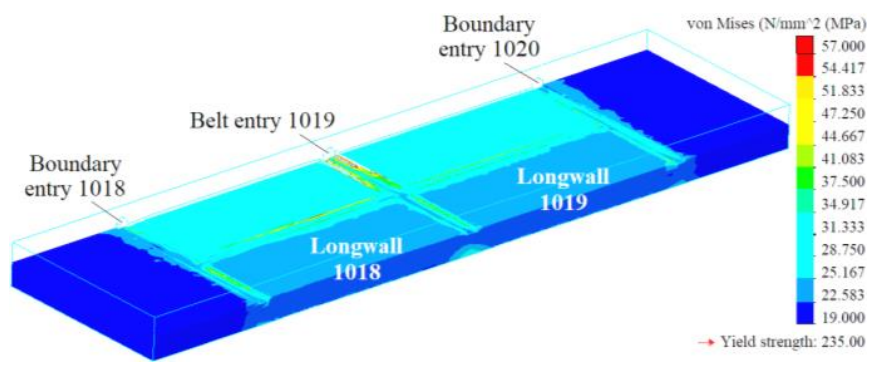

Figure 2. 3D section of a model of the reduced stresses of the rock mass in the process of long-pillar mining of a coal seam using the double-unit longwalls (distance between the longwalls is 0-0 $\mathrm{m}$ )

The use of the software package SolidWorks 2019 has made it possible to represent adequately the rock mass conditions when principles of dynamic, kinematic, and static similarity are kept. The important component of the development of such models has become the fact that a possibility arises to evaluate stress of the selected extraction pillar with the provision of the geometry immensity in accordance with the conversion factors making it possible to effect identity between relevant dimensions of the modeled object and nature object (static similarity).

Principles of kinematic similarity were applied to form correspondence between physical stress parameters of support pressure during certain time period; changes in it during the stope motion along the extraction pillar was simulated according to the dynamic similarity principles.

Visual simulation of the reduced stress values makes it possible estimate expansion of tensile deformations as well as compressive ones. On the other hand, differentiation of a stress field of a rock mass is the variable helping determine loads applied to the supports of the development mine workings and stopes.

Provision of relevant parameters and evaluation of the field stress on the basis of the determined reduced stresses $\sigma_{0}$ show how it is difficult to acquire the visual information due to the immensity of the obtained geometrical and physical parameters of the model. Moreover, verification of the modeling results has shown definite noncompliance of the results concerning rock mass behaviour with the actual situation. That is why we interpolated the reliability of the final results of the model object and nature object with the help of the common principle mentioned in paper [88]. It is provided by the use of so-called conformity factor:

$$
\mu=\frac{K_{m}}{K_{n}},
$$

where:

$K_{n}$ and $K_{m}$ - relevant dimensions or parameters of the qualitative characteristics of the nature and the model being simulated.

The data interpolation involved principles of rock mass stress evaluation based upon underground experiments described in reasonable detail by papers [88], [89]. Also, due to the fact, that in Ukraine to establish the loadings on the mechanized complexes is used the value of the ton-forces per square meter $\left(\mathrm{tf} / \mathrm{m}^{2}\right)$ instead of megapascals $(\mathrm{MPa})$, these value is used in estimating the field strength. The research was carried out using eight separate measuring stations in the place of the stopes and along the extraction pillar (by four in boundary entries 1018 and 1020). Unfortunately, it was impossible to carry out the research in a belt entry 1019 since the mine working was filled right after the longwalls were mined.

It should be noted that the research results within a longwall are compared with the values obtained in terms of a measuring station one along the extraction pillar length. Hence, the paper will focus on the changes in the field stress in the process of advance of the stopes. The total characteristic of distances of the measuring station in terms of the extraction pillar length is:

- measuring station $1-$ at the level of the stopes (maximum stresses);

- measuring station 2 - at the $1 / 6\left(l_{1} ;+l_{2}\right)$ distance from the stope plane;

- measuring station 3 -at the $1 / 3\left(l_{1} ;+l_{2}\right)$ distance from the stope plane;

- measuring station $4-$ at the $2 / 3\left(l_{1} ;+l_{2}\right)$ distance from the stope plane.

To represent the analyzed area visually with singling out of the parameters to be identified while evaluating stressstrain state of the rock mass under certain mining and geological conditions, we will demonstrate a diagrammatic view of stress changes for the studied double-unit stopes. $\sigma_{\text {Max } 0}=19.0 \mathrm{MPa}$ value, identified in a mine, will be taken up as the basis of for gradient stresses. The absolute stress values were also obtained owing to experiments in terms of station 4 , making it possible to consider the distance as that at which a conditional area of the rock mass stabilization is formed. Diagrammatic view of the coupled stopes shown on the Figure 3.

Relying upon the representation of stress-strain zone formation, it is possible to conclude that the determination of physical and geometrical parameters of the support pressure area is to define variable parameters $X_{i}$ (being a value of the support pressure area expansion) and $\sigma$ maxi (being a value of the total stress maximum) in terms of constant total values of lengths of the longwalls $\left(l_{1} ; l_{2}\right)$. It should be mentioned that the lengths of the longwalls are $l_{1}=185 \mathrm{~m}$ and $l_{2}=200 \mathrm{~m}$ respectively. Analysis of the rock mass behaviour helps draw a conclusion that in addition to its technological functions, belt entry 1019 also plays a role of a technogenic cavity being a source destressing carbonous formationn for the both stopes. 


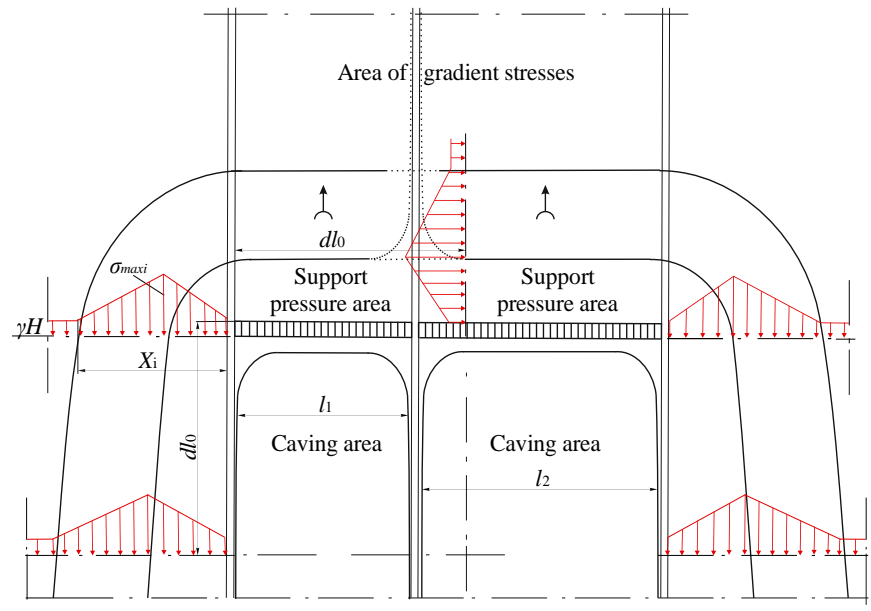

Figure 3. Diagrammatic view of the coupled stopes in terms of 0-0 position (the double-unit longwall): $X_{i}$-variable of the support pressure zone expansion, $m$; $d l_{0}$-half of the length of double-unit longwalls, $m ; l_{1}$ and $l_{2}$-lengths of the longwalls; and $\sigma_{\text {maxi-variable of the total stress }}$ maximum
To visualize the pattern of the support pressure formation, represent diagrammatic views of changes in the reduced stresses within the mentioned characteristic points (i.e. measuring stations). Since the stress values at a measuring station 4 are constant, there is no necessity to demonstrate them graphically. Figure 4 shows the curves.

Basing upon the stated expansion of the expanded stress field we find it necessary to identify formation of maximum stresses in the process of mining of the mentioned doubleunit longwalls. Figure 5 demonstrates a histogram of spatial changes in the reduced stresses. Table 2 demonstrates the physical and geometrical values characterizing changes in the stress-strain state of the rock mass within a support pressure area.

According to the graphs, shown in Figure 4, and relying upon the derived dependences it is possible to conclude that changes in spatial expansion of the reduced stresses can be represented in the form of the $3^{\text {rd }}$ degree polynomial dependences. They depend upon empirical coefficients $\left(a_{i}, b_{i}, c_{i}\right.$, and $d_{i}$ ) and may be formulated as follows:

$$
y_{i}=a_{i} x^{3}-b_{i} x^{2}+c_{i} x \pm d_{i}
$$

Table 2. Physical and geometrical parameters of a support pressure area in the process of the double-unit longwall operation

\begin{tabular}{|c|c|c|c|c|c|c|c|c|c|c|c|c|c|c|c|c|c|c|c|}
\hline \multirow{3}{*}{$\begin{array}{c}\text { Parameters } \\
X_{i}\end{array}$} & \multicolumn{19}{|c|}{ Physical and geometrical parameters of a support pressure area } \\
\hline & \multicolumn{19}{|c|}{ Distance from a conditional plane of the stope to the rock mass depth, $\mathrm{m}$} \\
\hline & 0 & 1 & 2 & 3 & 4 & 5 & 6 & 7 & 8 & 9 & 10 & 11 & 12 & 13 & 14 & 15 & 16 & 17 & 18 \\
\hline \multicolumn{20}{|c|}{ Stress changes along the support area length, $\mathrm{tf} / \mathrm{m}^{2}$} \\
\hline$\sigma_{\max 1}$ & 0 & 140 & 290 & 430 & 530 & 620 & 575 & 525 & 465 & 400 & 325 & 250 & 190 & 190 & 190 & 190 & 190 & 190 & 190 \\
\hline$\sigma_{\max 2}$ & 0 & 70 & 160 & 250 & 330 & 390 & 470 & 460 & 440 & 415 & 370 & 340 & 315 & 275 & 225 & 190 & 190 & 190 & 190 \\
\hline$\sigma_{\max 3}$ & 0 & 55 & 140 & 195 & 255 & 300 & 345 & 370 & 355 & 345 & 335 & 320 & 310 & 290 & 270 & 250 & 225 & 205 & 190 \\
\hline
\end{tabular}

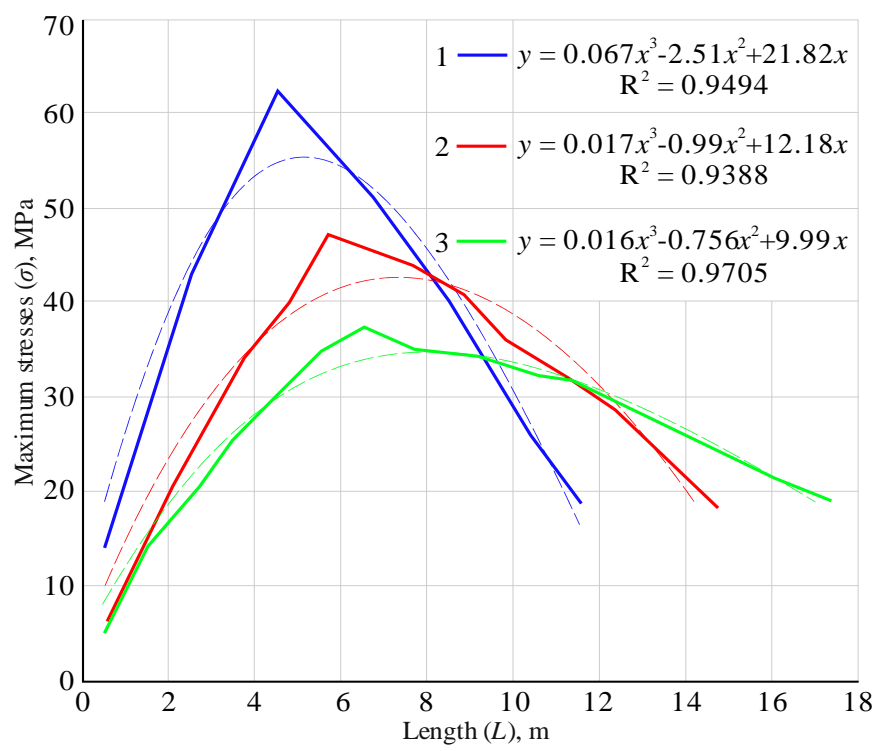

Figure 4. Graphical representation of the changes in the reduced stresses within a support pressure area of the doubleunit stopes: 1-3 measuring stations

Idealize the mining and geological conditions to generalize the results. Assume that our double-unit longwall is surrounded by the undisturbed rock mass. Hence, range of values of the reduced values is within $\notin(-\infty ;+\infty)$. Consequently, start of the stress changes from gradient ones is in some provisional spatial point to be considered as a zero reading. Draw the abscissa from the point in parallel with a line of the stopes.

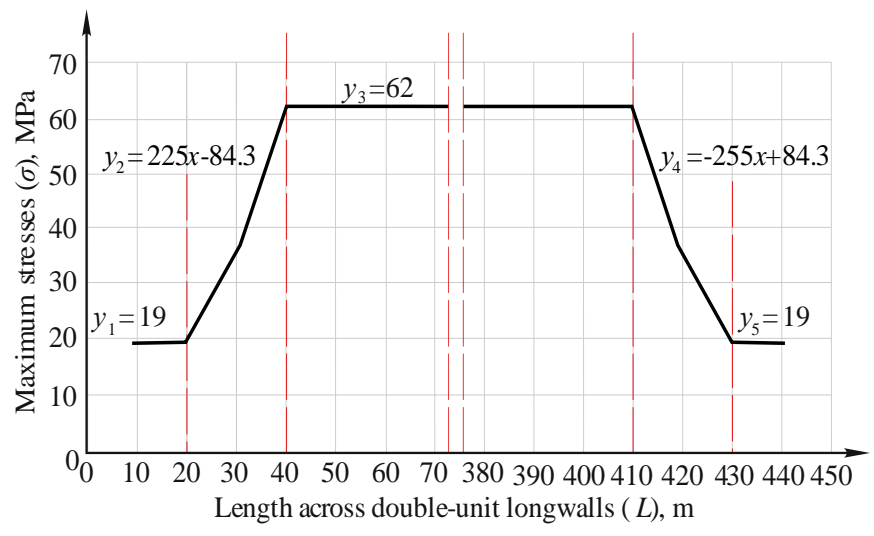

Figure 5. Histogram of spatial changes in the reduced stresses within the area of effect of the double-unit longwalls

Represent absolute values of the reduced stress range on the $y$-axis. Hence, within the determined distance from $0\left(X_{i}\right)$ for $L_{1}$ the stresses increase up to their maximum. Then $\left(L_{1}-L_{2}\right.$ interval) their stabilization takes place, and decrease down to gradient ones ( $L_{2}-L_{3}$ interval). In general, changes of a field stress of the two double-unit longwalls may be demonstrated in the form of following dependences:

$$
\begin{aligned}
& y_{1}=k y H \text { if } y \notin(-\infty ; 0] ; \\
& y_{2}=a X+b \text { if } y \notin\left(0 ; L_{1}\right] ; \\
& y_{3}=y_{\max }=\sigma_{\max } \text { if } y \notin\left[L_{1} ; L_{2}\right) ;
\end{aligned}
$$




$$
\begin{aligned}
& y_{4}=-a X+b \text { if } y \notin\left[L_{2} ; L_{3}\right) ; \\
& y_{5}=k y H \text { if } y \notin\left(L_{3} ;+\infty\right),
\end{aligned}
$$

where:

$$
k \gamma H-\text { a value of gradient stresses, } \mathrm{MPa}^{2} \text {; }
$$

$a$ and $b$ - the values of the empiric coefficients characterizing mining and geological as well as technical and technological situation of the analyzed sites.

So, it is possible to conclude that maximum of the reduced stresses of a support area of the double-unit stopes varies sectorally in terms of linear dependences along a provisional line located conventionally in parallel with the stopes. In this context, they are characterized by their gradual increase along the extraction pillar, stabilization along the longwalls, and gradual decrease while distancing from the stopes. The abovementioned makes it possible to forecast stress-strain state of rock mass in the process of mining concentration and to control rock pressure efficiently during coal extraction.

\section{Conclusions}

Use of the double-unit longwalls is one of the tendencies of mining concentration. Notably, such technical and technological improvement needs no extra financial injections since it is focused on the available mining equipment. Correct decisions concerning the rock pressure control as well as the basic operational schedules intended to mine coal and convey it, to support stopes and other measures, connected with provision of a mine site activities, help decrease power consumption drastically as well as expenditures for conveyance and support of mine workings. Finally, that results in the decreased prime cost of the coal.

The research has identified that formation of a support pressure area depends upon lithological and geological structures as well as upon physical characteristics of carbonous formation rocks. It is possible to define the area using SolidWorks 2019 software package and to verify the results with the help of underground experiments. Changes in the reduced stresses of carbonous formation have become the criterion for the field stress evaluation.

Maximum stresses are verified sectorally by means of linear dependences. Their maximum is at a certain distance from a stope plane. Gradual destressing is observed along the extraction pillar; they decrease down to gradient ones in the 2/3-3/2 interval of the longwall length. The final stress values are the basis to identify loads on the supports of mine workings and development workings. In turn, that helps select adequate technical and technological equipment for mining operations as well as methods of rock pressure control.

Verification of the data with the help of underground experiments has made it possible to obtain maximum credible results.

\section{Acknowledgements}

This paper contains the research conducted within the grant No.0120U102084 (financed by the Ministry of Education and Science of Ukraine), and Dubrovnik International ESEE Mining School (project in the framework of EIT Raw Materials).

\section{References}

[1] Pivnyak, G.G., \& Shashenko, O.M. (2015). Innovations and safety for coal mines in Ukraine. Naukovyi Visnyk Natsionalnoho Hirnychoho Universytetu, (6), 118-121.

[2] Wang, J., Yu, B., Kang, H., Wang, G., Mao, D., Liang, Y., \& Jiang, P. (2015). Key technologies and equipment for a fully mechanized topcoal caving operation with a large mining height at ultra-thick coal seams. International Journal of Coal Science \& Technology, 2(2), 97-161. https://doi.org/10.1007/s40789-015-0071-4

[3] Bondarenko, V., \& Dychkovskiy, R. (2006). Methods of extraction of thin and rather thin coal seams in the works of the scientists of the underground mining faculty (National Mining Uuniversity). New Technological Solutions in Underground Mining International Mining Forum, 21-25. https://doi.org/10.1201/noe0415401173.ch3

[4] Sribna, Y., Trokhymets, O., Nosatov, I., \& Kriukova, I. (2019). The globalization of the world coal market - contradictions and trends. E3S Web of Conferences, (123), 01044. https://doi.org/10.1051/e3sconf/201912301044

[5] Al-Chalabi, H., Lundberg, J., Ahmadi, A., \& Jonsson, A. (2014). Case study: Model for economic lifetime of drilling machines in the swedish mining industry. The Engineering Economist, 60(2), 138-154. https://doi.org/10.1080/0013791x.2014.952466

[6] Camargo, H.E., Thompson, J.K., \& Azman, A.S. (2017). The development of buy quiet options for the mining equipment industry. In 46th International Congress and Exposition on Noise Control Engineering, 131923.

[7] Petlovanyi, M., Lozynskyi, V., Zubko, S., Saik, P., \& Sai, K. (2019) The influence of geology and ore deposit occurrence conditions on dilution indicators of extracted reserves. Rudarsko Geolosko Naftni Zbornik, 34(1), 83-91. https://doi.org/10.17794/rgn.2019.1.8

[8] Lozynskyi, V., Medianyk, V., Saik, P., Rysbekov, K., \& Demydov, M. (2020). Multivariance solutions for designing new levels of coal mines. Rudarsko Geolosko Naftni Zbornik, 35(2), 23-32. https://doi.org/10.17794/rgn.2020.2.3

[9] Piwniak, G.G., Bondarenko, V.I., Salli, V.I., Pavlenko, I.I., \& Dychkovskiy, R.O. (2007). Limits to economic viability of extraction of thin coal seams in Ukraine. Technical, Technological and Economic Aspects of Thin-Seams Coal Mining, 129-132. https://doi.org/10.1201/noe0415436700.ch16

[10] Kumar, D. (2015). Application of modern tools and techniques for mine safety \& disaster management. Journal of The Institution of Engineers (India): Series D, 97(1), 77-85. https://doi.org/10.1007/s40033015-0071-y

[11] Dychkovskyi, R., Vladyko, O., Maltsev, D., \& Cáceres Cabana, E. (2018). Some aspects of the compatibility of mineral mining technologies. Rudarsko Geolosko Naftni Zbornik, 33(4), 73-82. https://doi.org/10.17794/rgn.2018.4.7

[12] Saik, P., Petlevanyi, M., Lozynskyi, V., Sai, K., \& Merzlikin, A. (2018). Innovative approach to the integrated use of energy resources of underground coal gasification. Solid State Phenomena, (277), 221-231. https://doi.org/10.4028/www.scientific.net/SSP.277.221

[13] Pavlychenko, A., \& Kovalenko, A. (2013). The investigation of rock dumps influence to the levels of heavy metals contamination of soil. Annual Scientific-Technical Collection - Mining of Mineral Deposits, 237-238. https://doi.org/10.1201/b16354-43

[14] Dychkovskyi, R.O. (2015). Determination of the rock subsidence spacing in the well underground coal gasification. Naukovyi Visnyk Natsionalnoho Hirnychoho Universytetu, (6), 30-36.

[15] Vladyko, O., Kononenko, M., \& Khomenko, O. (2012). Imitating modeling stability of mine workings. Geomechanical Processes During Underground Mining, 147-150. https://doi.org/10.1201/b13157-26

[16] Popovych, V., \& Voloshchyshyn, A. (2019). Features of temperature and humidity conditions of extinguishing waste heaps of coal mines in spring. News of the National Academy of Sciences of the Republic of Kazakhstan, Series of Geology and Technical Sciences, 4(436), 230-237. https://doi.org/10.32014/2019.2518-170X.118

[17] Bosak, P., \& Popovych, V. (2019). Radiation-ecological monitoring of coal mines of Novovolinsk mining area. News of the National Academy of Sciences of the Republic of Kazakhstan, Series of Geology and Technical Sciences, 5(437). 132-137. https://doi.org/10.32014/2019.2518$\underline{170 X .134}$

[18] Medvedieva, O., Lapshyn, Y., Koval, N., Zeynullin, A., \& Gupalo, O. (2020). The resource-saving technology to restore the accumulation ability of tailing ponds. E3S Web of Conferences, (168), 00054. https://doi.org/10.1051/e3sconf/202016800054

[19] Pivnyak, G., Dychkovskyi, R., Bobyliov, O., Cabana, E.C., \& Smoliński, A. (2018). Mathematical and geomechanical model in physical and chemical processes of underground coal gasification. 
Solid State Phenomena, (277), 1-16. https://doi.org/10.4028/www.scientific.net/ssp.277.1

[20] Golovchenko, A., Dychkovskyi, R., Pazynich, Y., Edgar, C.C., Howaniec, N., Jura, B., \& Smolinski, A. (2020). Some aspects of the control for the radial distribution of burden material and gas flow in the blast furnace. Energies, 13(4), 923. https://doi.org/doi:10.3390/en13040923

[21] Falshtyns’kyy, V., Dychkovs'kyy, R., Lozyns'kyy, V., \& Saik, P. (2013). Justification of the gasification channel length in underground gas generator. Annual Scientific-Technical Collection-Mining of Mineral Deposits, 125-132. doi:10.1201/b16354-23

[22] Sobolev, V., Bilan, N., Dychkovskyi, R., Cabana, E.C., \& Smolinski, A. (2020). Reasons for breaking of chemical bonds of gas molecules during movement of explosion products in cracks formed in rock mass. International Journal of Mining Science and Technology, 30(2), 265-269. https://doi.org/10.1016/j.ijmst.2020.01.002

[23] Chernai, A.V., Sobolev, V.V., Chernai, V.A., Ilyushin, M.A., \& Dlugashek, A. (2003). Laser ignition of explosive compositions based on di-(3-hydrazino-4-amino-1,2,3-triazole)-copper (II) perchlorate. Combustion, Explosion and Shock Waves, 39(3), 335-339. https://doi.org/10.1023/A:1023852505414

[24] Kovalevs'ka, I., Symanovych, G., \& Fomychov, V. (2013). Research of stress-strain state of cracked coal-containing massif near the working area using finite elements technique. Annual Scientific-Technical Collection - Mining of Mineral Deposits, 159-163. https://doi.org/10.1201/b16354-28

[25] Majkherchik, T., Gajko, G.I., Malkowski, P. (2002). Deformation process around a heading investigation when front of longwall face advancing. Ugol, (11), 27-29.

[26] Dychkovskyi, R.O. (2015). Forming the bilayer artificially created shell of georeactor in underground coal well gasification. Naukovyi Visnyk Natsionalnoho Hirnychoho Universytetu, (5), 37-42.

[27] Golovchenko, A, Pazynich, Yu, \& Potempa, M. (2018). Automated monitoring of physical processes of formation of burden material surface and gas flow in blast furnace. Solid State Phenomena, (277), 54-65. https://doi.org/10.4028/www.scientific.net/SSP.277.54 27

[28] Vagonova, O.G., \& Volosheniuk, V.V. (2012). Mining enterprises' economic strategies as derivatives of nature management in the system of social relations. Naukovyi Visnyk Natsionalnoho Hirnychoho Universytetu, (2), 127-134.

[29] Sinha, A. (2011). Underground coal mining: Technology-wise financial analysis. Journal of the Institution of Engineers (India): Mining Engineering Division, (92), 27-30.

[30] Fava, L., Maybee, B., \& Millar, D. (2012). Decision support for an underground gold mining operation - A case study using the schedule Optimisation tool. Australasian Institute of Mining and Metallurgy Publication Series, 41-48.

[31] Salama, A. (2017). Financial analysis of the impact of increasing mining rate in underground mining, using simulation and mixed integer programming. Journal of the Southern African Institute of Mining and Metallurgy, 117(4), 365-372. https://doi.org/10.17159/24119717/2017/v117n4a8

[32] Bondarenko, V.I., Griadushchiy, Y.B., Dychkovskiy, R. O., Korz, P.P., \& Koval, O.I. (2007). Advanced experience and direction of mining of thin coal seams in Ukraine. Technical, Technological and Economical Aspects of Thin-Seams Coal Mining, 2-7. https://doi.org/10.1201/noe0415436700.ch1

[33] Peng, S.P, Luo, L.P., \& Wang, J.N, (2003). Determination of rational staggered distance in double-long wall faces in mining on confined aquifer. Chinese Journal of Rock Mechanics and Engineering, 22(1), 48-52.

[34] Qin, W.L, \& Dai, R.L. (2002). Practice of double-unit face mining technology under complex geological conditions. Journal of Shandong University of Science and Technology, 21(2), 83-85.

[35] Guangqing, W. (2011). The practice of double-faced united corner blocks segment in mine. Value Engineering, (12), 232.

[36] Chen, X.H, Ma, M.S, \& Yan, Z.Q. (2005). The analysis of the strata control data of double-unit and single faces. Journal of Hebei Institute of Technology, 25(1), 2-5.

[37] Li, T.M, \& Shi, J.X. (1995). Strata behavior characteristics of double unit face in horizontal thick seam mining. Coal Mine Safety, (9), 6-9.

[38] Song, H., Wen, G., \& Li, J. (2008). The adjusting mining technology of combining fully mechanized with individual prop, rotating, hilt, irregular form, and double unit face on thin coal seam of Tianchen Mine. Journal of Coal Science and Engineering (China), 14(1), 44-48. https://doi.org/10.1007/s12404-008-0009-1

[39] Zhu, D., Tu, S., Tu, H., \& Yang, Z. (2019). Mechanisms of support failure and prevention measures under double-layer room mining gobs - A case study: Shigetai coal mine. International Journal of Mining Science and Technology, 29(6), 955-962. https://doi.org/10.1016/j.ijmst.2018.06.006
[40] Yu, M.X, Li, G.Y, Chen, X.H, Zhang, Z.Q, Zhang, H.J, \& Lu, G.Y. (2006). Roof management practice on transportation lane safety exports in opposite pulling faces. Jiangxi Coal Science \& Technology, (3), 24-25.

[41] Cao, Y.F. (2005). Double-unit coal mining technology for thin seam coal mining face with road retained for next sublevel. Coal Science and Technology, 33(9), 15-16.

[42] Fan, L.J., \& Yang, S.L. (2013). Technological optimization of fully mechanized caving mining face with large mining heights. Journal of Coal Science and Engineering (China), 19(3), 290-294. https://doi.org/10.1007/s12404-013-0304-3

[43] Smith, J.D. (1972). A mathematical investigation into the optimum ratio of plough and conveyor speeds in multi-plough bidirectional cutting. International Journal of Rock Mechanics and Mining Sciences \& Geomechanics Abstracts, 9(6), 767-781. https://doi.org/10.1016/01489062(72)90035-6

[44] Michalak, M., Sikora, B., \& Sobczyk, J. (2015). Diagnostic model for longwall conveyor engines. Man-Machine Interactions, (4), 437-448. https://doi.org/10.1007/978-3-319-23437-3_37

[45] Pivnyak, G., Razumny, Y., \& Zaika, V. (2009). The problems of power supply and power saving in the mining industry of Ukraine. Archives of Mining Sciences, 54(1), 5-12.

[46] Beshta, O.S. (2012). Electric drives adjustment for improvement of energy efficiency of technological processes. Naukovyi Visnyk Natsionalnoho Hirnychoho Universytetu, (4), 98-107.

[47] Pivnyak, G.G., Beshta, A.S., Zaika, V.T., \& Razumnyi, Yu.T. (2005). Regulation of electric power consumption at the Ukrainian mining enterprises. Gornyi Zhurnal, (5), 101-102.

[48] Golinko, V., Yavors'ka, O., \& Lebedev, Y. (2011). Substabtiation of the parameters of elements of mine vent systems while exploiting bedded deposits of horizontal occurence. Technical and Geoinformational Systems in Mining, 131-133. https://doi.org/10.1201/b11586-22

[49] Chen, S.W, Guo, J.F, \& Zhang, Y.S. (2004). The technology of doubleunit face mining share with return air system. Coal Engineering, (9), 7-8.

[50] Su, S., Chen, H., Teakle, P., \& Xue, S. (2008). Characteristics of coal mine ventilation air flows. Journal of Environmental Management, 86(1), 44-62. https://doi.org/10.1016/j.jenvman.2006.11.025

[51] Semin, M.A., \& Levin, L.Y. (2019). Stability of air flows in mine ventilation networks. Process Safety and Environmental Protection, (124), 167-171. https://doi.org/10.1016/j.psep.2019.02.006

[52] Sotskov, V., \& Saleev, I. (2013). Investigation of the rock massif stress strain state in conditions of the drainage drift overworking. Annual Scientific-Technical Collection - Mining of Mineral Deposits, 197-201. https://doi.org/10.1201/b16354-36

[53] Małkowski, P., Ostrowski, L., \& Bachanek, P. (2017). Modelling the small throw fault effect on the stability of a mining roadway and its verification by in situ investigation. Energies, 10(12), 2082. https://doi.org/10.3390/en10122082

[54] Khomenko, O.Ye. (2012). Implementation of energy method in study of zonal disintegration of rocks. Naukovyi Visnyk Natsionalnoho Hirnychoho Universytetu, (4), 44-54.

[55] Bondarenko, V.I., Kharin, Ye.N., Antoshchenko, N.I., \& Gasyuk, R.L. (2013). Basic scientific positions of forecast of the dynamics of methane release when mining the gas bearing coal seams. Naukovyi Visnyk Natsionalnoho Hirnychoho Universytetu, (5), 24-30.

[56] Sadovenko, I., Zahrytsenko, A., Podvigina, O., Dereviahina, N., \& Brzeźniak, S. (2018). Methodical and applied aspects of hydrodynamic modeling of options of mining operation curtailment. Solid State Phenomena, (277), 36-43. https://doi.org/10.4028/www.scientific.net/ssp.277.36

[57] Pivnyak, G., Beshta, A., \& Balakhontsev, A. (2010). Efficiency of water supply regulation principles. New Techniques and Technologies in Mining, 1-7. https://doi.org/10.1201/b11329-2

[58] Kuzlo, M.T., Moshynskyi, V.S., \& Martyniuk, P.M. (2018). Mathematical modelling of soil massif's deformations under its drainage. International Journal of Applied Mathematics, 31(6), 751-762. https://doi.org/10.12732/ijam.v31i6.5

[59] Mikhlin, Y.V., \& Zhupiev, A. L. (1997). An application of the Ince algebraization to the stability of non-linear normal vibration modes. International Journal of Non-Linear Mechanics, 32(2), 393-409. https://doi.org/10.1016/s0020-7462(96)00047-9

[60] Kovalev, A.M., Martynyuk, A.A., Boichuk, O.A., Mazko, A.G., Petryshyn, R.I., Slyusarchuk, V.Y., \& Slyn'ko, V.I. (2009). Novel qualitative methods of nonlinear mechanics and their application to the analysis of multifrequency oscillations, stability, and control problems. Nonlinear Dynamics and Systems Theory, 9(2), 117-145.

[61] Slyusarchuk, V.E. (1987). Weakly nonlinear perturbations of normally solvable functional-differential and discrete equations. Ukrainian Mathematical Journal, $39(5), \quad$ 540-542. https://doi.org/10.1007/BF01066475 
[62] Buzylo, V., Savelieva, T., \& Saveliev, V. (2012). Study of rock displacement with the help of equivalent materials using room-and-pillar mining method. Geomechanical Processes During Underground Mining, 29-34. https://doi.org/10.1201/b13157-6

[63] Malanchuk, Y., Moshynskyi, V., Korniienko, V., \& Malanchuk, Z. (2018). Modeling the process of hydromechanical amber extraction. E3S Web of Conferences, (60), 00005 https://doi.org/10.1051/e3sconf/20186000005

[64] Pivnyak, G., Bondarenko, V., Kovalevs'ka, I., \& Illiashov, M. (2012) Geomechanical Processes During Underground Mining. Book, 238 p. https://doi.org/10.1201/b13157

[65] Khalymendyk, I., \& Baryshnikov, A. (2018). The mechanism of roadway deformation in conditions of laminated rocks. Journal of Sustainable Mining, 17(2), 41-47. https://doi.org/10.1016/j.jsm.2018.03.004

[66] Sobko, B., Lozhnikov, O., Levytskyi, V., \& Skyba, G. (2019). Conceptual development of the transition from drill and blast excavation to non-blasting methods for the preparation of mined rock in surface mining. Rudarsko Geolosko Naftni Zbornik, 34(3), 21-28. https://doi.org/10.17794/rgn.2019.3.3

[67] Sdvizhkova, Ye.A., Babets, D.V., \& Smirnov, A.V. (2014). Support loading of assembly chamber in terms of Western Donbas plough longwall. Naukovyi Visnyk Natsionalnoho Hirnychoho Universytetu, (5), 26-32.

[68] Malkowski, P. (2016). Roadway design efficiency indices for hard coal mines. Acta Geodynamica et Geomaterialia, 201-211. https://doi.org/10.13168/agg.2016.0002

[69] Majcherczyk, T., Małkowski, P., \& Niedbalski, Z. (2008). Rock mass movements around development workings in various density of standing-and-roof-bolting support. Journal of Coal Science and Engineering, 14(3), 356-360. https://doi.org/10.1007/s12404-008-0078-1

[70] Dreus, A.Yu., Sudakov, A.K., Kozhevnikov, A.A., \& Vakhalin, Yu.N. (2016). Study on thermal strength reduction of rock formation in the diamond core drilling process using pulse flushing mode. Naukovyi Visnyk Natsionalnoho Hirnychoho Universytetu, (3), 5-10.

[71] Stupnik, M., Kolosov, V., Kalinichenko, V., \& Pismennyi, S. (2014). Physical modeling of waste inclusions stability during mining of complex structured deposits. Progressive Technologies of Coal, Coalbed Methane, and Ores Mining, 25-30. https://doi.org/10.1201/b17547

[72] Kalinichenko, V., Pysmennyi, S., Shvaher, N., \& Kalinichenko, O. (2018). Selective underground mining of complex structured ore bodies of Kryvyi Rih iron ore basin. E3S Web of Conferences, (60), 00041 https://doi.org/10.1051/e3sconf/2018600004

[73] Khomenko, O.Ye., Sudakov, A.K., Malanchuk, Z.R., \& Malanchuk, Ye.Z. (2017). Principles of rock pressure energy usage during underground mining of deposits. Naukovyi Visnyk Natsionalnoho Hirnychoho Universytetu, 2(158), 34-43.

[74] Bondarenko, V., Symanovych, G., \& Koval, O. (2012). The mechanism of over-coal thin-layered massif deformation of weak rocks in a longwall. Geomechanical Processes During Underground Mining, 41-44. https://doi.org/10.1201/b13157-8

[75] Adhikary, D.P., \& Guo, H. (2014). Modelling of longwall mininginduced strata permeability change. Rock Mechanics and Rock Engineering, 48(1), 345-359. https://doi.org/10.1007/s00603-014-0551-7
[76] Wang, X., Zhang, D., Zhang, C., \& Fan, G. (2013). Mechanism of mining-induced slope movement for gullies overlaying shallow coal seams. Journal of Mountain Science, 10(3), 388-397. https://doi.org/10.1007/s11629-013-2455-5

[77] Dychkovskyi, R.O., Lozynskyi, V.H., Saik, P.B., Dubiei, Y.V., Cabana, E.C., \& Shavarskyi, I.T. (2019). Technological, lithological and economic aspects of data geometrization in coal mining. Naukovyi Visnyk Natsionalnoho Hirnychoho Universytetu, (5), 22-28. https://doi.org/10.29202/nvngu/2019-5/4

[78] Dychkovskyi, R., Falshtynskyi, V., Ruskykh, V., Cabana, E., \& Kosobokov, O. (2018). A modern vision of simulation modelling in mining and near mining activity. E3S Web of Conferences, (60), 00014. https://doi.org/10.1051/e3sconf/20186000014

[79] Pivnyak, G., Dychkovskyi, R., Smirnov, A., \& Cherednichenko, Y (2013). Some aspects on the software simulation implementation in thin coal seams mining. Energy Efficiency Improvement of Geotechnical Systems, 1-10. https://doi.org/10.1201/b16355-2

[80] Hoek, E., \& Marinos, P. (2007). A brief history of the development of the Hoek-Brown failure criterion. Soils and Rocks, 30(2), 85-92.

[81] Wu, Y.F., \& Zhou, Y.W. (2010). Unified strength model based on Hoek-Brown failure criterion for circular and square concrete columns confined by FRP. Journal of Composites for Construction, 14(2), 175-184. https://doi.org/10.1061/(asce)cc.1943-5614.0000062

[82] Hoek, E., \& Brown, E.T. (1997). Practical estimates of rock mass strength. International Journal of Rock Mechanics and Mining Sciences, 34(8), 1165-1186. https://doi.org/10.1016/s1365-1609(97)80069-x

[83] Shashenko, A., Gapieiev, S., \& Solodyankin, A. (2009). Numerical simulation of the elastic-plastic state of rock mass around horizontal workings. Archives of Mining Sciences, 54(2), 341-348.

[84] Hoek, E. (1987). Practical rock engineering. London: Institution of Mining and Metallurgy. Book, $325 \mathrm{p}$.

[85] Brown, E.T., \& Hoek, E. (1998.). Determination of shear envelop in rock masses. Journal of Geotechnical Engineering, (3), 371-374.

[86] Carranza-Torres, C., \& Fairhurst, C. (1999). The elasto-plastic response of underground excavations in rock masses that satisfy the Hoek-Brown failure criterion. International Journal of Rock Mechanics and Mining Sciences, 36(6), 777-809. https://doi.org/10.1016/s01489062(99)00047-9

[87] Lee, Y.K. (2014). Derivation of Mohr envelope of Hoek-Brown failure criterion using non-dimensional stress transformation. Journal of Korean Society for Rock Mechanics, 24(1), 81-88. https://doi.org/10.7474/tus.2014.24.1.081

[88] Gritsko, G.I., \& Vlasenko, B.V. (1975). Obshchie printsipy otsenki napryazhennogo sostoyaniya massiva eksperimental'no-analiticheskim metodom mekhaniki gornykh porod. Analiticheskie Metody $i$ Vychislitel'naya Tekhnika v Mekhanike Gornykh Porod, 109-116.

[89] Gritsko, G.I., \& Tsytsarkin, V.N. (1995). Opredelenie napryazhennodeformirovannogo sostoyaniya massiva vokrug napryazhennykh plastovykh vyrabotok eksperimental'no-analiticheskim metodom. Fiziko-Tekhnicheskie Problemy Razrabotki Poleznykh Iskopaemykh, (3), 18-21

\section{Дослідження зміни напружено-деформованого стану масиву при роботі здвосних лав}

\section{Р. Дичковський, Я. Шаварський, П. Саїк, В. Фальштинський, Е. Кабана}

Мета. Обгрунтування характеру зміни напружено-деформованого стану гірського масиву при стовповій системі розробці вугільного пласта здвоєними лавами шляхом оцінки напруженості ділянки шахтного поля на прикладі роботи шахти ДП “Львіввугілля”.

Методика. На основі аналізу планів гірничих виробок проводиться оцінка фізичних та геометричних параметрів зони опорного тиску здвоєних очисних вибоїв залежно від гірничо-геологічних та гірничо-технічних умов відпрацювання вугільного пласта $n 7^{\mu}$. Рендеринг 3D моделі гірського масиву здійснювався за допомогою програмного продукту "SolidWorks 2019”. В основу побудови геомеханічної моделі гірського масиву прийняті вихідні дані щодо реальних умов при роботі здвоєних лав №1018 та 1019 (назви лав змінено на вимогу керівництва ДП “Львіввугілля") по пласту $n 7^{H}$ та паспортів кріплення підготовчих виробок шахти ДП “Львіввугілля”. Кожен елемент кріплення моделювався як окрема деталь, з відповідними фізико-механічними властивостями. Характер розповсюдження напружено-деформованого стану гірського масиву у вибраній точці досліджувався шляхом створення розрізів у заданій площині.

Результати. Розроблений алгоритм рендерингу 3D моделі гірського масиву при стовповій системі розробки вугільного пласта здвоєними лавами. Обгрунтовано геомеханічну модель гірського масиву залежно від гірничо-геологічних умов залягання та гірничотехнічних параметрів ведення процесу видобування вугілля.

Наукова новизна. Досліджено характер формування зон опорного тиску попереду очисного вибою та вздовж виймального стовпа. Встановлено, що при знаходженні очисних вибоїв в одній площині відбувається об'єднання їх фронтальних зон опорного тиску та боків підготовчих виробок. При цьому суміжний штрек окрім виконання своїх технологічних функцій виконує роль додаткової розвантажувальної техногенної порожнини.

Практична значимість. На основі досліджень напружено-деформованого стану гірського масиву при роботі здвоєних лав встановлено вихідні дані для розробки рекомендацій щодо раціональних параметрів ведення гірничих робіт та способів управління 
гірським тиском. Візуальне відображення принципів формування напружено-деформованого стану зони опорного тиску та оцінки стану масиву показало, що максимальні приведені напруження досягають 70 МПа при ширині зони опорного тиску 18 м.

Ключові слова: шахта, вугілля, гірський масив, здвоєні очисні вибої, виробка, напружено-деформований стан

\section{Исследование изменения напряженно-деформированного состояния массива при работе сдвоенных лав}

\section{Р. Дычковский, Я. Шаварский, П. Саик, В. Фальштинский, Э. Кабана}

Цель. Обоснование характера изменения напряженно-деформированного состояния горного массива при столбовой системе разработке угольного пласта сдвоенными лавами путем оценки напряженности участка шахтного поля на примере работы шахты ГП “Львовуголь”.

Методика. На основе анализа планов горных выработок проводится оценка физических и геометрических параметров зоны опорного давления сдвоенных очистных забоев в зависимости от горно-геологических и горно-технических условий отработки угольного пласта $n 7^{t}$. Рендеринг 3D модели горного массива осуществлялся с помощью программного продукта "SolidWorks 2019". В основу построения геомеханической модели горного массива приняты исходные данные о реальных условиях при работе сдвоенных лав №1018 и 1019 (названия лав изменены по требованию руководства ГП “Львовуголь”) по пласту $n 7^{*}$ и паспортов крепления подготовительных выработок шахты ГП “Львовуголь”. Каждый элемент крепления моделировался как отдельная деталь, с соответствующими физико-механическими свойствами. Характер распространения напряженно-деформированного состояния горного массива в выбранной точке исследовался путем создания разрезов в заданной плоскости.

Результаты. Разработанный алгоритм рендеринга 3D модели горного массива при столбовой системе разработки угольного пласта сдвоенными лавами. Обоснована геомеханическая модель горного массива в зависимости от горно-геологических условий залегания и горнотехнических параметров ведения процесса добычи угля.

Научная новизна. Исследован характер формирования зон опорного давления впереди очистного забоя и вдоль выемочного столба. Установлено, что при нахождении очистных забоев в одной плоскости происходит объединение их фронтальных зон опорного давления и сторон подготовительных выработок. При этом смежный штрек кроме выполнения своих технологических функций выполняет роль дополнительной разгрузочной техногенной полости.

Практическая значимость. На основе исследований напряженно-деформированного состояния горного массива при работе сдвоенных лав установлены исходные данные для разработки рекомендаций относительно рациональных параметров ведения горных работ и способов управления горным давлением. Визуальное отображение принципов формирования напряженнодеформированного состояния зоны опорного давления и оценки состояния массива показало, что максимальные приведенные напряжения достигают 70 МПа при ширине зоны опорного давления 18 м.

Ключевые слова: шахта, уголь, горный массив, сдвоенные очистные забои, выработка, напряженно-деформированное состояние

\section{Article info}

Received: 10 September 2019

Accepted: 22 April 2020

Available online: 4 May 2020 